ROCZNIKI HUMANISTYCZNE

Tom LXIX, zeszyt $12-2021$

DOI: https://doi.org/10.18290/rh216912-15

\title{
GENRE AND STYLE DIRECTIONS OF ADAPTATION FOR THE VIOLA IN THE WORKS OF UKRAINIAN COMPOSERS OF THE TWENTIETH CENTURY
}

Viola art of the late twentieth and early twenty-first century is experiencing an extraordinary rise, which was stimulated primarily by great achievements in performance, pedagogy and composition of the twentieth and twenty-first centuries. Modern domestic composers' creative works significantly differ in genre and style innovations. There is a constant interaction between genre and style, which depends, on the one hand, on the musical-historical process rules and on the other - on the genre hierarchical subordination to the style.

As far as the genre is concerned, we can note a constant interaction of traditional and new genres, and the emergence of new ones according to new imagery. The development of genre palette is constantly influenced by both musical material presenting technique and latest world-style aesthetic requirements, which gave rise to the preconditions for emergence of composers' mentality neoclassical basis.

In solo musical works adaptations, including for the viola, we find a number of very interesting discoveries associated with the peculiar features of the twentieth century mentality. It is worth emphasising that adaptation and reference to the "borrowed word" in various respects - as well as the original works - are intensively evolving and sometimes acquire very unusual forms.

Dr YAROSLAVA BARDASHEVSKA - Przykarpacki Uniwersytet Narodowy im. Wasyla Stefanyka w Iwano-Frankiwsku; adres do korespondencji: ul. Szewczenki 57, 76018 Iwano-Frankowsk [вул. Шевченка, 57, 76018 м. Івано-Франківськ], Ukraina; e-mail: yaroslava.bardashevska@gmail.com; ORCID: https://orcid.org/0000-0002-2315-9757.

Dr YARoslava BaRDASHEVSKA, Vasyl Stefanyk Precarpathian National University in IvanoFrankivsk; address for correspondence: 57 Shevtchenko St., 76018 Ivano-Frankivsk [вул. Шевченка, 57, 76018 м. Івано-Франківськ], Ukraine; e-mail: yaroslava.bardashevska@gmail.com; ORCID: https://orcid.org/0000-0002-2315-9757. 
The staunchest exponents of such innovative mentality in adaptations genres are justly considered to be the luminaries of Ukrainian viola art of the twentieth century like Zenon Dashak, Dmytro Gavrylets, Pavlo Makarenko, Irynei Turkanyk and many other prominent artists.

Genre-style repertoire for that kind of orchestral-stringed instrument as the viola includes such areas as musical works adaptation and transcription written for other musical instruments, classical, pop and jazz works.

The most interesting transcriptions of the above-mentioned composers are adaptations of famous violin works: Hutsul song by Alexander Znosko-Borovskii (Zenon Dashak), Dance by Yakiv Stepovyii (Zenon Dashak), Poetic moment by Alexey Riabov (Turkanyk), Melody by Miroslav Skoryk (Dmytro Gavrylets), Sottovoce by Anna Gavrylets (Dmytro Gavrylets) and other examples of the most sensual, associatively expressive, and obviously democratic music in Ukraine.

Considering the authors' approach to viola adaptations by Zenon Dashak and Irynei Turkanyk, as well as other composers of the twentieth century, we should refer to the interpretation concept. As you know, the standard meaning of interpretations is the comprehension of text content. However, based on the special priorities of the modern era, text content is not objectively embedded in the text due to the author's interpretation, and filling the text with content is not related to the question of its interpretative "correctness" or so-called "adequacy". That is why the text with all its characteristics is only a prerequisite for subtext formation. In composers' interpretations-adaptations the "subtext", in comparison even with similar genres of the Romantics, consists in expressly emphasised and stylised creation of the past epoch image, refined outplaying and mystification of audience, which requires a transcription that would convey the spirit of the original.

Analysing the transcriptions and adaptations of Ukrainian composers as one of the brightest twentieth-century models of genre transformation, it should be noted that they reproduced the unusually characteristic trends of aesthetic and stylistic pursuits of their time. On the one hand, an author of musical works constantly looks like a follower of romantic traditions and a bright post-romantic performer; on the other, like as a modern mentality representative in the sense in which spiritual leadership is modified in the post-war world.

There is a very clear polarisation of musical culture in general, about which the eminent philosopher Jose Ortega y Gasset wrote with such anxiety:

General public will always oppose Art Nouveau (the new art). It is unpopular by nature, moreover, it is anti-popular. Any of its works automatically has a very interesting sociological impact on the general public. It divides mass into two groups: one, very 
small, is a small number of supporters; another, large - the enemy majority. Thus, the work of art acts as a social agent, forming two antagonistic groups from the shapeless mass of the crowd, dividing the mass into two different castes. [Ortega y Gasset 150]

The niche between these extremes was filled by the academic music of the past. Zenon Dashak, on the other hand, was often qualified by elite connoisseurs as a popular trend performer that favours the general public. His numerous adaptations in various genre guises ultimately reflected most music lovers' natural nostalgia for high and beautiful art, which can be both apprehensible and emotional. That is why he and many other violin composers (or transcribers) change the very idea, the very function of various musical adaptation: with their help artists actualise a fairly large layer of "harmony of the past", bringing it closer to the contemporary audience's interests. In this context, a musical work as a realised musical text in terms of dialogue with the past acts for the performer as a means of particularly powerful influence on the listener, and for the listener - not just as a way to get new information, but also as an opportunity to empathise and nostalgically return to the beautiful past, full of harmony and kindness.

Another very important function, which is performed by the adaptation genre in the twentieth century music and which composer Dmytro Gavrylets brilliantly felt and conveyed both in his performing practice and in his creative work is the play function. The category of play is understood here in its modern sense, when a special conditional situation is created - the rules of play - which are accepted by both parties, while one party (the performer) offers and represents it; the other (listeners) perceive it and imaginatively, meaningfully decode it. The musical and stylistic level of play structure implementation reflects the manifestation of play principles in specific artistic and expressive means and techniques. This is both the most visual and the most characteristic level of manifestation of the playing principles in music of various styles and trends.

Undoubtedly, for the creator this play structure is marked as the initial in all his performing and composing work. The initial idea of concert performance for the artist, first of all, concerns competition and is manifested in a diverse dimension. The necessity to reach the highest level in this special creative process becomes a motivating incentive for the entire complex of the famous violist's artistic achievements. It seems that this is also facilitated by the exceptional extroversion of the composer's creative personality, which is always aimed at "open communication" with the broad audience, which basically denies closed elitism situation. 
This play principle is also clearly represented in Pavlo Makarenko's creative heritage, and the "mosaic" of his compositional (and performing) mentality is manifested primarily in the widest range of stylistic and genre models with which he "plays". Combinatorics of romantic/modern, baroque/modern interaction and interpenetration is not only one of his individual style essential features, but also the most fascinating, attractive feature for several subsequent generations of listeners, a special artistic task that they are happy to perform, "decoding" hidden meanings and building figurative and semantic vertical between different national schools and historical epochs.

Summarising the peculiarities of perception and sharing of viola adaptation genres in the twentieth century music on the example of Ukrainian composers' works, one should pay attention to their operation ontological conditionality, i.e. to the context. After all, it is the musical-historical context that determines a certain dominant perception of the author's idea in a musical text. The extramusical context (i.e., all that is associated with the musical medium) is a characteristic time setting for the perception of this kind of works. In the twentieth century there happens a rapid reorientation of axiological norms due to the blurring of boundaries and possibilities of representing any type of music in any situation and combination (one of the most characteristic examples is classical music panorama or classical motifs use in mobile phones ringtones). Moreover, play structure in viola transcriptions and adaptations serves as a convincing confirmation of the reflection in each significant artefact of the general civilisation processes of the specific historical period. That is why not every context is capable of interacting with the text given. And a piece of music can be forgotten, not relevant, and suddenly get a new life, become performed again; or change not the time but the audience of its existence.

A special type of "reverse adaptation" is formed, i.e., sound modelling in a stylised form, as if it was really performed in this way. But whereas nobody can now guess how the music of distant epochs really sounded, such attempts, which attract a fairly wide audience, i.e., perform the same social and educational functions and at the same time have a significant impact on the public, as was the case with romantic transcriptions 150 years ago, can be interpreted as "adaptation for adaptation", i.e., modelling of an ancient artefact from the standpoint of the modern idea of "antiquity". Since they easily get along with other types of adaptations in concert programs, we have every right to talk about expanding the artistic and semantic field of adaptations in the postmodern society.

Thus, the characteristic stylistic features of modern Ukrainian viola music are: transformation of musical forms and genres; musical intonation linked 
with the concentration of symbolic, semantic and formative structures; accentuation of folklore and ethno-cultural dimensions; attracting the latest means of musical expression.

The musical genre as a cultural phenomenon, although having a historical origin and specified existence conditions, at the same time opens to the composer a wide stylistic potential of culture, forces to choose and expand its spiritual resource, develop and implement new stylistic ways of understanding music.

\section{BIBLIOGRAPHY}

Dashak, Anna. "Zenon Dashak: shtrykhy do portretu myttsia." Stryiska DMSh im. O. Nyzhankivskoho: istoriia ta suchasnyi vymir: Materialy Mizhnarodnoi naukovo-teoretychnoi Konferentsii, 2013, pp. 281-291 [Дашак, Анна. «Зенон Дашак: штрихи до портрету митця». Стрийська ДМШ ім. О. Нижанківського: історія та сучасний вимір: Матеріали Міжнародної науково-теоретичної конференції, 2013, сс. 281-291].

Horbachevska, Yarina. "Dyskurs altovykh transkryptsii pershoi polovyny XX st." Mystetstvoznavchi zapysky: zbirnyk naukovykh prats, no. 24, 2013, pp. 112-119 [Горбачевська, Ярина. «Дискурс альтових транскрипцій першої половини XX ст.». Мистеиттвознавчі записки: збірник наукових праць, № 24, 2013, сс. 112-119].

Krysa, Oleg. "Dynamika stanovlennia altovoho repertuaru v konteksti vzaiemodii kompozytorskoi ta vykonavskoi shkil Kyieva." Vykonavske muzykoznavstvo, vol. 14, Zbirnyk statei, 2008, pp. 100-111 [Криса, Олег. «Динаміка становлення альтового репертуару в контексті взаємодії композиторської та виконавської шкіл Києва». Виконавське музикознавство, кн. 14: Збірник статей, 2008, сс. 100-111].

Ortega y Gasset, José. Dehumanizatsiia mystetstva. Vybrani tvory. Translated by Oleksandr Tovstenko, Osnovy, 1994 [Ортега-і-Гассет, Хосе. Дегуманізація мистецтва. Вибрані твори. Пер. Олександр Товстенко, Основи, 1994].

Romaniuk, Vitaly. Dashak Zenon - muzykant (altyst), vchenyi kompozytor, pedahoh (1928-1993). Stryishchyna: naukovo-populiarne vydannia, 2012 [Романюк, Віталій. Дашак Зенон-музикант (альтист), вчений композитор, педагог (1928-1993). Стрийщина: науково-популярне видання, 2012]. 